Mr. Dwight urged that closer relationships with conservationists and others indirectly interested in forestry would be most beneficial to the Society, and did not think that their admission as affiliate members would detract from the Socicty's prestige. Mr. Gibson opposed the modification of the qualifications for affiliate membership. The objects of the Society were read by Mr. Craig at Mr. Winegar's request. Mr. Winegar believed that these objects did not imply the admission of conservationists. Mr. Manning desired closer co-operation with conservationists and tourist organizations, but did not think that their membership in the C.S.F.E. was the proper way to achieve such co-operation. He suggested a broader organization to accomplish this. Mr. Dickson supported this view. Messrs. Irwin and Marritt suggested that the sections sponsor such action. Mr. Kilby recommended co-operation with the Canadian Forestry Association. Other speakers on the subject were $\mathrm{Mr}$. Macdonald, Mr. Craig and Col. Stevenson. The motion was finally carried.

Recommendation No. 13-That the words "in Canada" be deleted from Article III, for requirements of membership. Carried without discussion.

Recommendation No. 15 urged members to buy memberships certificates. Acting on a suggestion by Mr. Manning, that the Treasurer collect money for the certificates immediately, 37 members at once subscribed.

Recommendation No. 14-That application for membership in regions where sections are not formed shall be made to the membership committee of the general Socicty, as now.

Mr. Brown asked whether dues should be collected by the General Executive in such cases. The President replied that this would be so. Carried.

The President thanked Dr. Howe and the members of the Policy Committee for the work they had accomplished.

\title{
DISCUSSION ON FOREST POLICY
}

The President then brought up the question of how the Society might best put before the public its conception of a forest policy for the country. He referred to the proposed Forestry Congress which was still under consideration, and asked for a discussion of publicity methods.

Mr. Manning, speaking with regard to British Columbia, said that at present the Canadian Forestry Association was the medium used for forestry publicity, but this would not necessarily continue. He was not prepared to say what, if anything, the C.S.F.E. should do in the matter of publicity.

Mr. MacDougall believed the C.S.F.E. should give leadership in formulating forest policies for Canada, but did not think the Society should itself undertake the publicity work required to bring them to the attention of the general public. 
Mr. Dickson said that he had good reason to believe that the C.F.A. was looking for the support of the professional foresters once more.

Mr. Kilby thought this was an opportune time to make overtures to the C.F.A. and the Society should actively support that organization and make representations to this end at its next annual meeting, preferably by word of mouth rather than the presentation of a formal resolution in writing.

Mr. Irwin thought the Society might approach various service clubs with a view to arousing interest in forestry. It might also interest certain independent newspapers as well as fish and game clubs. He favoured the formation of a committee of the Society to attend to publicity.

The President remarked that $\mathrm{Mr}$. Irwin's independent position eminently qualified him to act on such a committee.

Mr. Dickson spoke highly of the value of the radio in publicity work of this kind.

Mr. Manning believed that the Society must make up its mind whether the C.F.A. is a proper medium to promote forestry publicity or not. If so we should co-operate with it, if not, we should sever all connections.

The concensus of opinion of the meeting was that the C.F.A., in theory at least, should be the ideal medium for publicity if properly administered.

Mr. Manning said the C.F.A. must have the courage of its convictions if it is to be successful and worthy of support.

Mr. MacDougall seconded by Mr. Davison moved that this meeting request the Executive to appoint a small committee to prepare a report on forest policy for the consideration of the Society. Motion carried.

\section{MEMBERSHIP CERTIFICATES}

Mr. Andrews spoke strongly against the present wording of the Society's certificates and suggested their recall as they offended legally recognized professional organizations and did not reflect favourably upon the Society. $\mathrm{He}$ nade the following motion, seconded by Mr. Dickson:

That whereas the membership certificates as at present drawn up and worded conflict in a manner incompatible with the dignity of the C.S.F.E., in that they antagonize the various associations of professional engineers existing under provincial legislation, it is moved that a new certificate be drawn up and carefully worded so as to be within our own rights, and that only these new certificates be issued in future, and that the old certificates which have been issued be exchanged for the new.

Mr. Kilby, seconded by $\mathrm{Mr}$. Irwin, moved an amendment to $\mathrm{Mr}$. Andrew's motion, as follows: 